\title{
EXPLOITATION AND DESTABILIZATION OF A WARM, FRESHWATER ECOSYSTEM THROUGH ENGINEERED HYDROLOGICAL CHANGE
}

\author{
K. David Hambright, ${ }^{1,2,7}$ Tamar Zohary, ${ }^{2}$ Werner Eckert, ${ }^{2}$ Steven S. Schwartz, ${ }^{2,3,8}$ Claire L. Schelske, ${ }^{4}$ \\ Kathleen R. Laird, ${ }^{5}$ and Peter R. Leavitt ${ }^{6}$ \\ ${ }^{1}$ Program in Ecology and Evolutionary Biology, Biological Station and Department of Zoology, University of Oklahoma, \\ Norman, Oklahoma 73019 USA \\ ${ }^{2}$ Israel Oceanographic \& Limnological Research, Kinneret Limnological Laboratory, Migdal 14950 Israel \\ ${ }^{3}$ Department of Zoology, Oklahoma State University, Stillwater, Oklahoma 74078 USA \\ ${ }^{4}$ Land Use \& Environmental Change Institute, Department of Geological Sciences, University of Florida, \\ Gainesville, Florida 32611 USA \\ ${ }^{5}$ PEARL, Department of Biology, Queen's University, Kingston, Ontario K7L 3 N6 Canada \\ ${ }^{6}$ Limnology Laboratory, Department of Biology, University of Regina, Regina, Saskatchewan S4S0A2 Canada
}

Abstract. Exploitation of freshwater resources is having catastrophic effects on the ecological dynamics, stability, and quality of those water resources on a global scale, especially in arid and semiarid regions. Lake Kinneret, Israel (the Biblical Sea of Galilee), the only major natural freshwater lake in the Middle East, has been transformed functionally into a reservoir over the course of $\sim 70$ years of hydrological alterations aimed mostly at producing electrical power and increasing domestic and agricultural water supply. Historical changes in lake chemistry and biology were reconstructed using analysis of sedimentary nutrient content, stable and radioisotope composition, biochemical and morphological fossils from algae, remains of aquatic invertebrates, and chemical indices of past light regimes. Together, these paleolimnological analyses of the lake's bottom sediments revealed that this transformation has been accompanied by acceleration in the rate of eutrophication, as indicated by increased accumulation rates of phosphorus, nitrogen, organic matter, phytoplankton and bacterial pigments, and remains of phytoplankton and zooplankton. Substantial increases in these indices of eutrophication coincide with periods of increased water-level fluctuations and drainage of a major upstream wetland in the early to middle 20th century and suggest that management of the lake for increased water supply has degraded water quality to the point that ecosystem stability and sustainability are threatened. Such destabilization may be a model for eutrophication of freshwater lakes in other arid regions of the world in which management emphasizes water quantity over quality.

Key words: arid-region lake; ecosystem stability; eutrophication; Lake Kinneret, Israel; lake management; paleolimnology; water quality degradation; water-resource exploitation.

\section{INTRODUCTION}

Exploitation of freshwater resources is depleting the quantity of fresh water available for domestic and agricultural needs and may be having catastrophic effects on the ecological dynamics, stability, and quality of exploited water resources (Postel et al. 1996, Vitousek et al. 1997). This is especially true in the arid and semiarid regions of Africa and central Asia, and in the Middle East (Micklin 1988, Oganesian and Parparov 1989, Coe and Foley 2001, Gleick 2004, Hambright and Zohary 2005) where water management is further complicated by political constraints inherent in exploitation of trans-boundary water resources (Wolf 1995, Yoffe et al. 2003). Unfortunately, there is only limited

Manuscript received 5 June 2007; revised 11 February 2008; accepted 7 March 2008. Corresponding Editor: D. D. Breshears.

${ }^{7}$ E-mail: dhambright@ou.edu

8 Present address: 161 Willard Road, Brookline, Massachusetts 02455 USA. understanding of how such complex hydrological exploitation affects water quality in managed lakes.

Freshwater resources of Lake Kinneret, Israel, the Biblical Sea of Galilee, and the only major natural freshwater lake in the Middle East, have been exploited for millennia, although the degree and rate of exploitation have been particularly high during the past century (Hambright et al. 2004, Zohary 2004). The potential impacts of such exploitation have gone largely undocumented because systematic scientific monitoring of the lake began only in 1969 (Serruya 1978) and baseline data reflecting earlier conditions in the lake are not available. As such, Lake Kinneret has historically been considered a naturally eutrophic lake, with high annual primary production, seasonal development of deepwater anoxia, and characteristic blooms of dinoflagellates (Serruya 1978, Berman et al. 1995).

Lake Kinneret has been a relatively stable ecosystem for most of the previous three decades (Berman et al. 1992, Reynolds 2002). However, since 1994, the phytoplankton have exhibited elevated variability (Fig. 1), with 

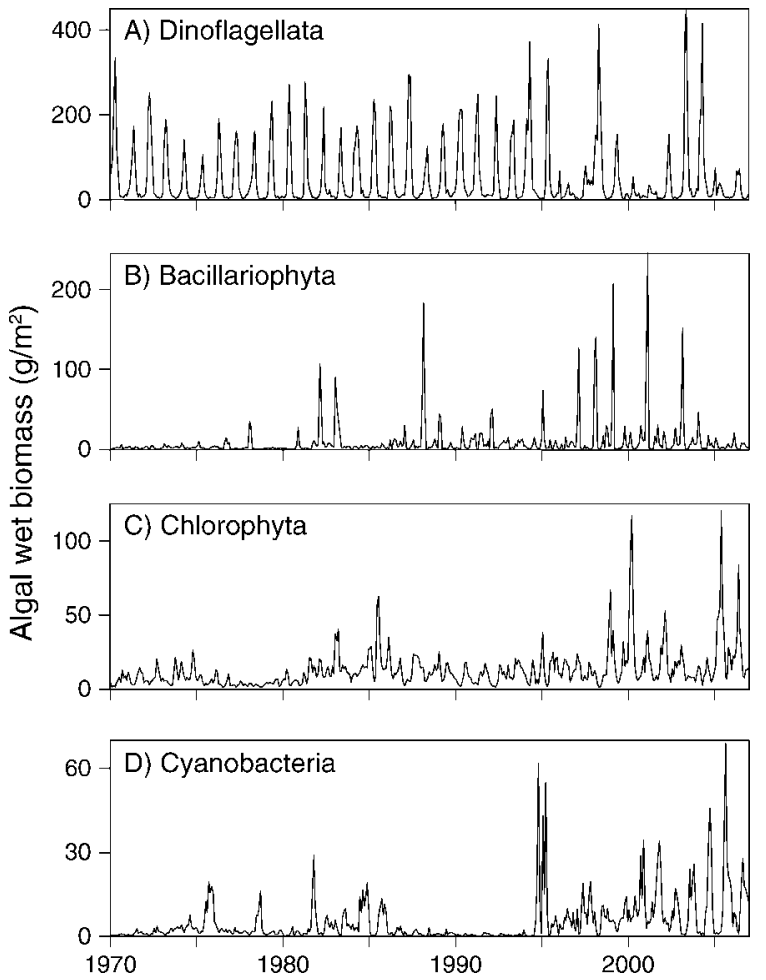

FIG. 1. Areal biomass (wet mass) of major algal taxonomic groups in Lake Kinneret, Israel, during 1970-2006 as recorded by the ongoing routine monitoring program of the Kinneret Limnological Laboratory. (A) Characteristic spring blooms of dinoflagellates, mostly Peridinium gatunense, in the lake through 1995, after which Peridinium failed to bloom in six out of ten years. (B) Diatoms (Bacillariophyta) were minor components in the algal assemblage until the 1980s, with major increases in abundances since 1995. (C) Chlorophytes, which typically dominated the algal assemblage between successive Peridinium blooms, increased markedly in the 1980 s, with record blooms in the 1990s. (D) Cyanobacteria abundances were highly variable but low (note the different scale) during the first 25 years, with no N-fixing species present, but they have become common components of the algal assemblage, including summer blooms of N-fixing species, since 1994 (for details of phytoplankton monitoring, analyses, and species composition, see Berman et al. [1998], Pollingher et al. [1998], and Zohary [2004]).

successive record blooms of the spring alga Peridinium in 1994, 1995, 1998, 2003, and 2004 and their recruitment failures in 1996, 1997, 2000, 2001, 2005, and 2006, the onset of unprecedented outbreaks of $\mathrm{N}$-fixing, and potentially toxic, cyanobacteria (Aphanizomenon ovalisporum, Cylindrospermopsis cuspis), and the increased prevalence of other cyanobacteria, as well as green algae and diatoms (Zohary 2004). Such high variability is characteristic of other ecosystem destabilizations that result from human-induced lake eutrophication (Schindler 1987, Cottingham et al. 2000, Carpenter 2005). Explicit reasons for these dramatic developments are unproven, although increased external and internal nutrient influx, modified lake hydrology, and inappropriate fisheries practices may have been involved (Hambright et al. 1997, 2004, Roelke et al. 2007).
Paleolimnological analyses of a suite of biological, chemical, and physical sedimentary characteristics were undertaken to quantify changes in ecosystem structure and production that occurred prior to modern ecological monitoring and coincident with intense hydrological management since the 1930s. We hypothesized that variability in plankton and food-web structure in recent decades (Zohary 2004) arose because of long-term lake eutrophication (cf. Cottingham et al. 2000) that originated as a result of lake management for increased water supply and protection of water quality, but which increased nutrient retention within the lake basin (Hambright et al. 2004). Because such modifications are common and increasing in arid and semiarid regions of the world, we believe that Lake Kinneret provides a general model for lake management in dry-land ecozones.

\section{Methods}

\section{Study site description}

Lake Kinneret is a warm, monomictic lake located between $32^{\circ} 42^{\prime}$ and $32^{\circ} 53^{\prime} \mathrm{N}$, at $-209 \mathrm{~m}$ altitude in the north of Israel in the Dead Sea Rift Valley (part of the Afro-Syrian Rift Series). The lake is moderately large (surface area $=169 \mathrm{~km}^{2}$; volume $=4.3 \mathrm{~km}^{3}$ ) with average temperatures typically ranging from $14-16^{\circ} \mathrm{C}$ during the homeothermic winter period to $29-31^{\circ} \mathrm{C}$ in the epilimnion during the peak of thermal stratification.

At present, Lake Kinneret is classified as naturally eutrophic, with seasonal phytoplankton blooms reaching values up to $300 \mathrm{~g}$ wet mass $/ \mathrm{m}^{2}$ and a seasonal anoxic hypolimnion (Serruya 1978, Berman et al. 1995). For nearly three decades, Lake Kinneret phytoplankton and primary production fluctuated in highly predictable patterns (Zohary 2004). Typically, Peridinium gatunense, a large $(50-\mu \mathrm{m}$ diameter) dinoflagellate, accounted for $\sim 50 \%$ of the annual primary production and usually constituted $>95 \%$ of the phytoplankton biomass in winter and spring. Nanoplanktonic $(<20 \mu \mathrm{m})$ chlorophytes, cryptophytes, and diatoms constituted the remaining winter-spring phytoplankton biomass. Toward the end of the Peridinium bloom, smaller $(\sim 20-30$ $\mu \mathrm{m})$ dinoflagellates became abundant and, during summer and autumn, nanoplanktonic forms predominated. For most of the period during which Lake Kinneret has been monitored (i.e., since 1969), these algal assemblages have been assumed to be characteristic of the natural state of the ecosystem (sensu Pollingher 1981, Berman et al. 1992).

Since the mid-1990s the phytoplankton assemblage of Lake Kinneret has exhibited increasing variation in algal-species composition. For example, the magnitude of the spring blooms of Peridinium has varied from historical maxima to years in which no bloom occurred (Fig. 1). Similarly, winter blooms of the filamentous diatom Aulacoseira granulata have intensified, summer biomass levels of nanoplanktonic algal species have increased, and nitrogen-fixing and toxin-producing cyanobacteria have appeared and now dominate the 


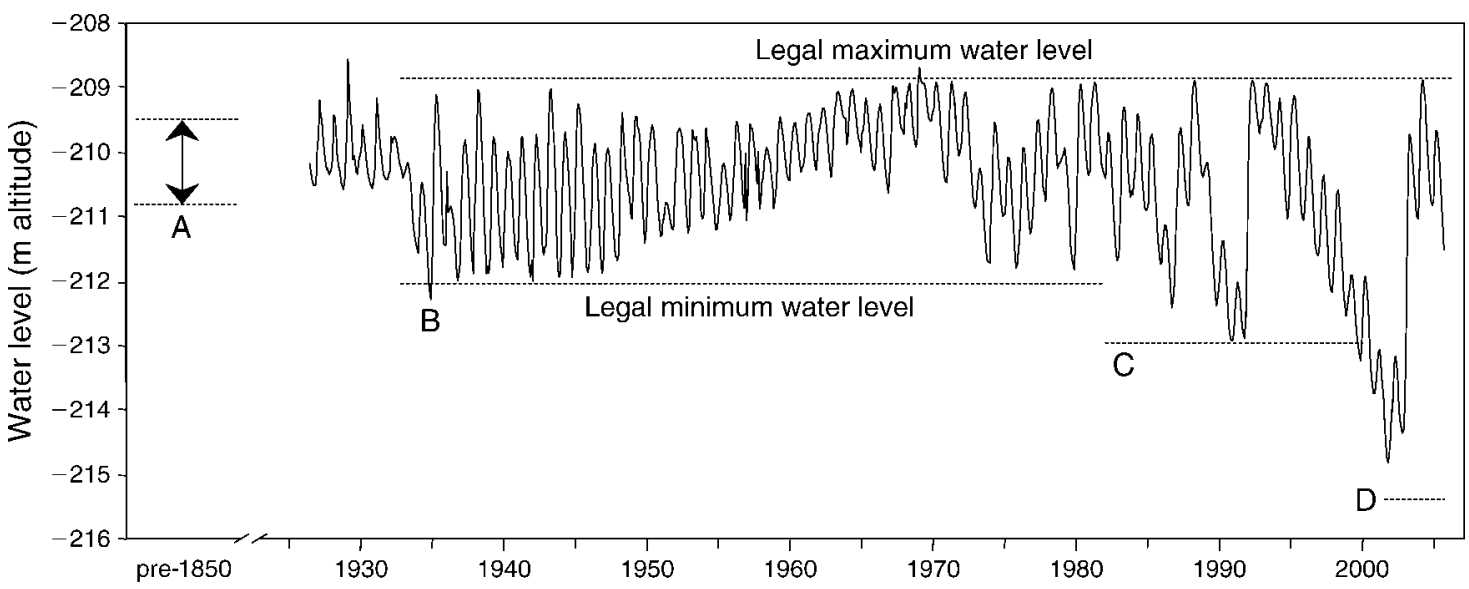

FIG. 2. A long-term record of Lake Kinneret monthly mean water levels since the initiation of routine measurements in 1926. (A) The two-headed arrow indicates the range of natural water-level fluctuations prior to the $1850 \mathrm{~s}$, based on archeological evidence (Nun 1974). (B) The upper and lower legal limits at $-209 \mathrm{~m}$ and $-212 \mathrm{~m}$ altitude respectively, as defined by law under the British Mandate. (C) In 1981 the legal lower limit was lowered to $-213 \mathrm{~m}$ altitude by the Israeli government, to allow increased pumping during drought years. (D) In August 2001 the legal lower limit was lowered further to $-215.5 \mathrm{~m}$, to allow continued pumping of water during a period of a regional water-shortage crisis.

summer and fall assemblages (Zohary 2004, Roelke et al. 2007).

The zooplankton assemblage of Lake Kinneret is dominated at present by small crustaceans (Ceriodaphnia, Bosmina, Chydorus, Mesocyclops, Thermocyclops) and numerous species of rotifers and protists (Gophen 1992, Hambright et al. 2007). Although the cladoceran Daphnia lumholtzi was recorded in the lake prior to 1956 (Bromley 1993) and the large calanoid copepod Eudiaptomus drieschi appeared briefly between 1992 and 1996 (Azoulay 2002), large species of zooplankton are rare. Until recently, Lake Kinneret supported a commercial fishery based mostly on the endemic zooplanktivore Kinneret bleak (Acanthobrama terraesanctae), two native planktivorous cichlids (Sarotherodon galileaus and Oreochromis aurea), and three exotic planktivores, silver carp (Hypothalmichthyes molitrix), and grey mullets (Liza remada, Mugil cephalus) (Ben-Tuvia et al. 1992). Improved fishing techniques and annual stocking of native cichlids and exotic carp (ceased in 1985) and mullet increased commercial harvest during the 1970s and 1980s (Gophen et al. 1983a, b). However, following an intensification of harvest on larger individuals beginning in the mid-1980s, the bleak fishery collapsed in 1993 (Hambright and Shapiro 1997) leading to an increased population of small-sized bleak and possibly lower zooplankton biomass (Ostrovsky and Walline 2001). A culling program aimed at increasing mean individual bleak body size and increasing zooplankton biomass began in 1995 (Ostrovsky and Walline 2001), but the bleak population and the bleak fishery have yet to recover (Zohary and Gasith 2006).

\section{Historical natural and anthropogenic events}

Due to the characteristics of the local Mediterranean climate, with alternations between rainy winters and dry summers, seasonal fluctuations in water levels have been an integral feature of the Kinneret ecosystem since the lake formed approximately 20000 years ago (Serruya 1978). Based on archaeological evidence, Nun (1974) concluded that natural water levels in Lake Kinneret fluctuated seasonally over a range of about $1.3 \mathrm{~m}$ (between -209.5 and $-210.8 \mathrm{~m}$ altitude) between the 12th and 19th centuries (Fig. 2). This amplitude of fluctuation, as well as the relatively low maximum water level $(-209.5 \mathrm{~m})$, were apparently maintained by the presence of two outlets at the southern end of the lake: a narrow (30-40 m), relatively deep outlet through which small floods passed (the modern-day Jordan River outlet), and a wider $(150 \mathrm{~m})$ but shallower outlet a few kilometers northwest of the Jordan River, through which large volumes of water flushed when the lake level rose during heavy floods. Over time, the shallower outlet gradually filled in with sediments and, by the mid1800 s, closed completely. With only the narrow Jordan River outlet, the maximum water levels in the lake increased by $\sim 0.5 \mathrm{~m}$, although, with the exception of the unusual flood years of 1918-1919 and 1928-1929, the overall amplitude of annual fluctuations remained below $1.3 \mathrm{~m}$ through the first quarter of the 20th century (Hambright et al. 2004).

Beginning in the late 1920 s a series of engineered hydrological changes (Table 1) converted Lake Kinneret into a reservoir, with two distinct periods of increased water-level fluctuations: 1932-1948 and 1973-present. During 1927-1932 (project completed in June 1932), the lake was impounded and the Jordan River outlet was deepened to supply water for hydroelectric production (Serruya 1978). Seasonal water-level fluctuations averaged $2.1 \pm 0.6 \mathrm{~m}$ (mean $\pm \mathrm{SD}$ ) during the period of operation of the hydroelectric station (1932-1948). Water levels gradually returned to natural variability 
TABLE 1. Important historical natural and anthropogenic events recorded for Lake Kinneret, Israel.

\begin{tabular}{|c|c|c|}
\hline Year & Event & Reference \\
\hline $1100-1800$ & natural water-level fluctuations (between -209.5 and $-210.8 \mathrm{~m}$ altitude & Nun (1974) \\
\hline 1918-1919 & heavy winter rains, local flooding & Nun (1974) \\
\hline 1928-1929 & heavy winter rains, local flooding & Nun (1974) \\
\hline $1927-1932$ & $\begin{array}{l}\text { lake impounded; outflow deepened from }-211 \text { to }-214.5 \mathrm{~m} \text { altitude; } \\
\text { hydroelectric production began; legal maximum and minimum water } \\
\text { levels set at }-208.9 \text { and }-212 \mathrm{~m} \text { altitude, respectively }\end{array}$ & Serruya (1978) \\
\hline 1948 & hydroelectric production ceased & Serruya (1978) \\
\hline 1951-1957 & Lake Hula and surrounding swamp in northern catchment drained & $\begin{array}{l}\text { Stiller (1979), } \\
\quad \text { Dimentman et al. (1992) }\end{array}$ \\
\hline 1964 & National Water Carrier completed & Serruya $(1978)$ \\
\hline 1968-1969 & heavy winter rains, local flooding & Serruya (1978) \\
\hline 1973 & National Water Carrier at full operation & Serruya (1978) \\
\hline 1970s & channelization of the Jordan River upstream of Lake Kinneret & Stiller (1979) \\
\hline 1981 & legal minimum water level reduced to $-213 \mathrm{~m}$ altitude & Hambright and Zohary (2005) \\
\hline 1983 & sewage from northern watershed diverted for agricultural use & Zohary (2004) \\
\hline 1985 & $\begin{array}{l}\text { shift in net mesh size by Kinneret bleak fishermen leading to increased } \\
\text { harvest pressure on large fish }\end{array}$ & Hambright and Shapiro (1997) \\
\hline 1991 & record low water level ( $-213 \mathrm{~m}$ altitude) & Hambright et al. (1997) \\
\hline 1991-1992 & heavy winter rains, local flooding; record water-level increase $(4.1 \mathrm{~m})$ & Hambright et al. (1997) \\
\hline 1993 & collapse of Kinneret bleak fishery & $\begin{array}{l}\text { Hambright and Shapiro (1997), } \\
\text { Ostrovsky and Walline (2001) }\end{array}$ \\
\hline 1994 & partial reflooding of Hula Valley; creation of Lake Agmon & Hambright and Zohary (1999) \\
\hline 1994 & first appearance of $\mathrm{N}$-fixing cyanobacteria (Aphanizomenon ovalisporum) & Zohary (2004) \\
\hline 1995-2006 & biomanipulation (attempted culling of Kinneret bleak population) & Hambright and Shapiro (1997) \\
\hline 1996 & no Peridinium bloom; first appearance of Planktolyngbya sp. & Zohary (2004) \\
\hline 1997 & no Peridinium bloom & Zohary (2004) \\
\hline 1998 & complete isolation of Hula Valley drainage from Kinneret catchment & Zohary (2004) \\
\hline 2000 & $\begin{array}{l}\text { no Peridinium bloom; first appearance of a second } \mathrm{N} \text {-fixing } \\
\text { cyanobacterium (Cylindrospermopsis cuspis) }\end{array}$ & Zohary (2004) \\
\hline 2001 & $\begin{array}{l}\text { legal minimum water level reduced to }-215.5 \mathrm{~m} \text { altitude; record low } \\
\text { water level of }-214.9 \mathrm{~m} \text { altitude; no Peridinium bloom }\end{array}$ & $\begin{array}{l}\text { Zohary (2004), Hambright and } \\
\text { Zohary (2005) }\end{array}$ \\
\hline $2002-2003$ & heavy winter rains, local flooding; new record water-level increase $(5 \mathrm{~m})$ & Fig. 2 \\
\hline 2003 & record Peridinium bloom & T. Zohary (unpublished data) \\
\hline 2004 & new record Peridinium bloom; second collapse of the bleak fishery & $\begin{array}{l}\text { T. Zohary (unpublished data); } \\
\text { J. Shapiro (personal communication) }\end{array}$ \\
\hline 2005 & $\begin{array}{l}\text { no Peridinium bloom, a spring Debarya sp. (new invader) bloom instead, } \\
\text { massive Cylindrospermopsis bloom in summer-fall }\end{array}$ & T. Zohary (unpublished data) \\
\hline 2006 & no Peridinium bloom, Debarya sp. bloom instead & T. Zohary (unpublished data) \\
\hline
\end{tabular}

until Lake Hula and its surrounding wetland $\left(\sim 60 \mathrm{~km}^{2}\right)$ on the Jordan River in Lake Kinneret's northern watershed was drained in the 1950s (completed 1957) to reduce evaporative water losses, increase arable land for agriculture, and to eradicate malaria (Dimentman et al. 1992). With the completion of Israel's National Water Carrier (NWC) in 1964, the major outflow of the lake was shifted from the Jordan River outlet at the south end of the lake to the northwest intake of the NWC, and Lake Kinneret was converted into the primary storage and supply reservoir for the country's fresh water. Since 1973 the NWC has operated at full capacity, minimum legal water levels have been lowered several times (currently at $-215.5 \mathrm{~m}$; Table 1), seasonal water-level fluctuations have increased to $1.8 \pm 0.9 \mathrm{~m}$, and the maximum seasonal fluctuation has exceeded $5 \mathrm{~m}$.

In addition to hydrological modifications aimed at increasing water supply, the food web of Lake Kinneret has been subjected to both nutrient and fisheries management (Table 1). In an effort to limit nutrient loading from the growing population and agricultural developments in the northern watershed of Lake Kinneret, a small reservoir (Einan) was constructed and used to collect urban and agricultural sewage in 1983 (Zohary 2004). Although the commercial fisheries of Lake Kinneret have been regulated since the 1930s (Ben-Tuvia et al. 1992), harvest in the dominant Kinneret bleak fishery shifted to larger sizes beginning in 1985 and resulted in long-term overharvest, reduction of mean body sizes, and eventual collapse of the fishery in 1993 (Hambright and Shapiro 1997). The resulting smaller mean body sizes in the bleak population (Ostrovsky and Walline 2001) yielded increased predation pressure on zooplankton (sensu Brown et al. 2004), leading to reduced zooplankton biomass and mean body sizes, and possibly further food-web alterations (Roelke et al. 2007; K. D. Hambright, unpublished manuscript). In order to rectify increasing problems associated with the Lake Hula draining project in the 1950s, including soil subsidence, peat fires, dust storms, and high nitrogen loading to Lake Kinneret, a portion of the Hula Valley was reflooded in 1994 using a network of canals and a small $1-\mathrm{km}^{2}$, shallow lake (Lake Agmon) (Hambright and Zohary 1999). The lake and canal network were isolated hydrologically from the Jordan 
River in 1998 to further reduce nutrient loading to Lake Kinneret from the Hula Valley (Zohary 2004).

\section{Paleolimnological analyses}

Given that Lake Kinneret and its watershed have experienced major human-induced change since at least the 1930 s, we attempted to quantify baseline characteristics of the lake by examining the historical record contained in the lake's sediments. Nine 5-cm-diameter sediment cores (each $36 \mathrm{~cm}$ long; extending back to the late $1800 \mathrm{~s}$ ) were taken using a gravity corer within a $25-$ $\mathrm{m}^{2}$ area from the central region of Lake Kinneret in March 1995 and analyzed for various geochemical and biological constituents. Eight cores were sliced into $1-\mathrm{cm}$ increments and the 36 individual slices from each core were combined into 36 composite samples (Pennington et al. 1973, Hambright et al. 2004). Dried $\left(105^{\circ} \mathrm{C}\right.$ for 24 h) sediment samples were analyzed by $\gamma$-spectroscopy of ${ }^{210} \mathrm{~Pb},{ }^{214} \mathrm{Bi}$, and ${ }^{137} \mathrm{Cs}$ activities by $\mathrm{A}$. Bollhöfer (Radiometrische Altersbestimmung von Wasser und Sedimenten, Heidelberger Akademie der Wissenschaften, Heidelberg, Germany) following Bollhöfer et al. (1994) and used to establish the core chronology based on the constant-rate-of-supply model (Goldberg 1963, Appleby and Oldfield 1983). The established chronology was verified using three independent biomarkers and, from an independent core taken in 2002, a second $\gamma$ spectroscopy analysis following Schelske et al. (1994). For further details of core chronology, see Hambright et al. (2004). Organic-matter content was determined by standard mass loss-on-ignition procedures (Leavitt and Findlay 1994). Sediment P concentrations were measured by colorimetry following chemical oxidation (Hambright et al. 2004). Accumulation rates of total sediments (as dry mass), organic matter, and phosphorus were estimated as mass per square meter per year.

The ninth core was analyzed for pigments from phytoplankton and bacteria, zooplankton exoskeletons (mainly Bosmina), phytoplankton remains (mainly Peridinium cysts), and $\mathrm{C}$ and $\mathrm{N}$ content and isotopic composition. The core was sectioned in 1-cm intervals and stored under an $\mathrm{N}_{2}$ atmosphere to prevent oxidation of pigments. Subsamples for pigment and $\mathrm{C}$ and $\mathrm{N}$ analyses were frozen in the dark until transport to the laboratory where they were freeze-dried $24 \mathrm{~h}$ at $0.01 \mathrm{~Pa}$ and stored under a $\mathrm{N}_{2}$ atmosphere (dark, $-20^{\circ} \mathrm{C}$ ) for 24 $\mathrm{h}$ before further analysis (Leavitt et al. 1989). Sediments were prepared for analysis of fossil pigments following standard procedures (Leavitt et al. 1989, Leavitt and Findlay 1994). Carotenoids, chlorophylls (Chls) and their derivatives were extracted $\left(18 \mathrm{~h}, 4^{\circ} \mathrm{C}\right.$, dark, under $\mathrm{N}_{2}$ ) from freeze-dried sediments using a mixture of acetone: methanol: water $(80: 15: 5$, by volume). Sediment residues were extracted exhaustively with three aliquots of solvent mixture, extracts filtered $(0.22-\mu \mathrm{m}$ Acropore membrane [Millipore Corporation, Billerica, Massachusetts, USA]), and solvents evaporated in the dark using $\mathrm{N}_{2}$ gas. Dried extracts were stored at $-20^{\circ} \mathrm{C}$ under $\mathrm{N}_{2}$ in the dark until pigment analysis. Just prior to quantification, pigments were brought to room temperature in the dark and dissolved in a precisely known volume of injection solvent (acetone:ion-pairing reagent:methanol; 70:25:5, by volume) containing 3.2 mg/L Sudan II (Sigma Chemical Company, Oakville, Ontario, Canada). This chromatographic dye is an internal standard that has carotenoid-like absorption characteristics ( $\lambda_{\max }=485,442.5 \mathrm{~nm}$ in acetone), runs at a unique position on the chromatogram $(7.3 \mathrm{~min})$ between aphanizophyll (7.0 $\mathrm{min}$ ) and myxoxanthophyll (7.6 min), and is used to correct for dilution, injection, and chromatographic errors (Leavitt and Findlay 1994). Ion-pairing reagent (IPR) consisted of $0.75 \mathrm{~g}$ tetrabutyl ammonium acetate and $7.7 \mathrm{~g}$ ammonium acetate in 100 mL water.

Concentrations of fossil pigments were quantified using a Hewlett Packard model 1050 high-performance liquid chromatograph (HPLC) equipped with an in-line HP model 1050 photodiode array spectrophotometer and an HP model 1046A fluorescence detector (Agilent Technologies Canada, Mississauga, Ontario, Canada). All analyses used the reversed-phase procedure of Mantoura and Llewellyn (1983), as modified by Leavitt et al. (1989) and Leavitt and Findlay (1994). Pigment fluxes were expressed as millimoles of pigment per square meter per year. In addition, historical changes in water clarity were reconstructed following Brown et al. (1984). Their water clarity index (WCI) is a dimensionless ratio of isorenieratene: $\beta$-carotene carotenoids that are individually characteristic of green sulfur bacteria and all algae, respectively. Because green sulfur bacteria are obligate anaerobes, they inhabit the deepest layer of the photic zone (including surficial sediments) and are subject to shading and population collapse due to low light associated with elevated algal biomass. In cases where water column stratification is stable, changes in WCI are proportional to light penetration to anoxic waters.

Content of elemental $\mathrm{N}$ and $\mathrm{C}$ (percentage dry mass) and isotopic composition $\left(\delta^{15} \mathrm{~N}, \delta^{13} \mathrm{C}\right)$ were determined by mass spectrometry of subsamples treated in a similar manner as detailed for pigments. All samples were freeze-dried $24 \mathrm{~h}$ at $0.01 \mathrm{~Pa}$ and stored under a $\mathrm{N}_{2}$ atmosphere in the dark at $-20^{\circ} \mathrm{C}$ until analysis using our standard procedures (Savage et al. 2004).

For zooplankton analyses, known amounts $(\sim 0.5 \mathrm{~g}$ wet mass) of each core slice were deflocculated in boiling $10 \% \mathrm{KOH}$, concentrated by centrifugation, and washed twice in deionized water following Kerfoot (1981). Resuspended fossil subsamples were transferred to a 3$\mathrm{mL}$ sedimentation chamber and analyzed under an inverted microscope $(200 \times)$. All zooplankton remains were identified to genus if possible, and morphology measured according to Kerfoot (1981). Prior to counting, a few drops of $3 \% \mathrm{HCl}$ were added to the sedimentation chamber to dissolve calcite crystals. Fossil accumulation rates for the most abundant taxon 


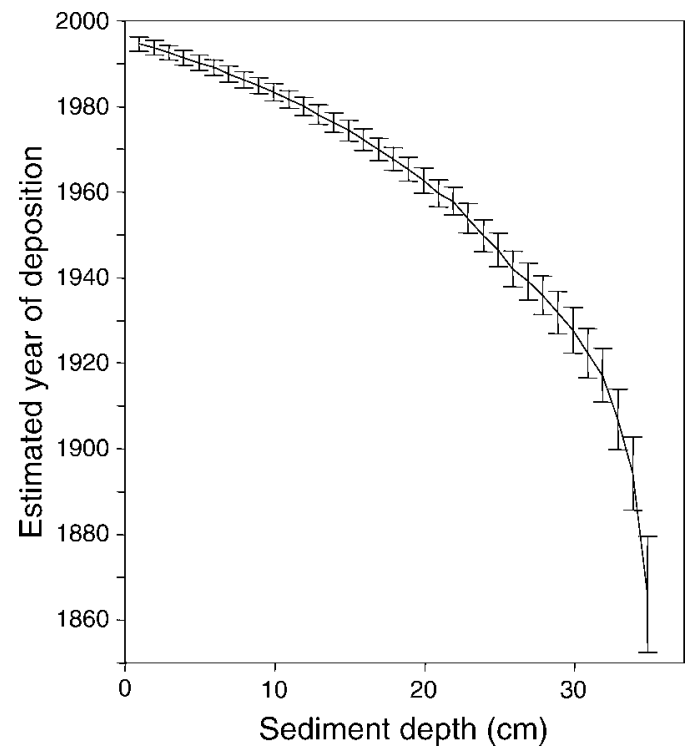

FIG. 3. Estimated year of deposit $( \pm 95 \%$ CI $)$ for $1-\mathrm{cm}$ sections of sediment core plotted against sediment depth.

(Bosmina) were estimated as individuals per square meter per year.

For Peridinium analyses, a known amount $(\sim 0.5 \mathrm{~g}$ wet mass) of each depth interval was suspended in $100 \mathrm{~mL}$ of deionized water and preserved with Lugol's iodine (2\%). Peridinium remains typically included either cell membranes or resting cysts, both easily identifiable as remnants of Peridinium (Zohary et al. 1998). Algal fossils were counted using an inverted microscope at $200 \times$ in $3-$ $\mathrm{mL}$ subsamples until 100 cells had been observed or the entire sample had been examined. Changes in Peridinium abundance were estimated from fossil accumulation rates as cells per square meter per year.

\section{Statistical analysis}

Stratigraphically constrained cluster analysis was performed using CONISS in the program TILIA version 2.02 (Grimm 1987) to identify local fossil-assemblage zones and to tentatively identify dates of coherent change in fossil assemblages. Cluster analysis was conducted on all core metrics combined (i.e., accumulation rates of sediment, phosphorus, nitrogen, organic matter, pigments, plankton remains, stable isotopes, water clarity index) after being centered and standardized $($ mean $=0, \mathrm{SD}=1)$. Analyses were completed on untransformed data from all parameters, except $\delta^{13} \mathrm{C}$ data that were transformed to absolute values. Although most fossils were present in all samples, we also used linear interpolation between adjacent samples to fill missing values. Local assemblage zones were estimated using a standard Euclidian distance dissimilarity coefficient. No attempt was made to evaluate the statistical significance of individual clusters, instead the clusters were used as an objective metric to establish approximate dates of synchronous community change.

\section{RESUlts}

The ${ }^{210} \mathrm{~Pb}$-based chronology for the core, including documentation of independent biomarkers, has been reported elsewhere (Hambright et al. 2004). Briefly, the core provides a record of sediment accumulation from the last third of the 19th century $(35 \mathrm{~cm}$ represents the year $1866 \pm 13.5 \mathrm{yr}[$ mean $\pm 95 \% \mathrm{CI}])$ to $1995(1994 \pm$ $1.6 \mathrm{yr}$ ), the year of core collection (Fig. 3). Bulk sediment-accumulation rate (SAR) shows a gradual increase from the 1860 s through the early 1900s (from 0.11 to $0.29 \mathrm{~kg}$ dry mass $[\mathrm{DM}] \cdot \mathrm{m}^{-2} \cdot \mathrm{yr}^{-1}$ ), with a steady increase (up to $0.98 \mathrm{~kg} \mathrm{DM} \cdot \mathrm{m}^{-2} \cdot \mathrm{yr}^{-1}$ ) since the early 20th century floods and the 1932 impoundment (Fig. 4). Because of greater uncertainty in the ages of older samples (95\% CIs range: 7-13.5 yr; cf. Fig. 3), it is not possible to discern the unique effects of increased waterlevel fluctuations due to the floods and dam construction. However, concomitant with the increased waterlevel fluctuations following impoundment (ca. 19321948), SAR remained high but relatively constant $\left(\sim 0.82 \mathrm{~kg} \mathrm{DM} \cdot \mathrm{m}^{-2} \cdot \mathrm{yr}^{-1}\right)$ until the draining of the Lake Hula wetland (1951-1957). Following the peak of 1.54 $\mathrm{kg} \mathrm{DM} \cdot \mathrm{m}^{-2} \cdot \mathrm{yr}^{-1}$ in $1957( \pm 3.2 \mathrm{yr})$, SAR gradually increased to $\sim 1.86 \mathrm{~kg} \mathrm{DM} \cdot \mathrm{m}^{-2} \cdot \mathrm{yr}^{-1}$ until $1984( \pm 1.9$ $\mathrm{yr}$ ), approximately coincident with the Einan sewage

FIG. 4. Records of past water-level fluctuations and a suite of fossil records of water quality and production in Lake Kinneret, Israel, during the late 19th and 20th centuries as determined from sediment cores. Time series include: (A) annual water-level fluctuations beyond the natural background level of $1.3 \mathrm{~m}$ (Hambright et al. 2004); accumulation rates of (B) bulk sediments (S, dry mass) and phosphorus (P) (Hambright et al. 2004), (C) nitrogen and $\delta^{15} \mathrm{~N}$ for organic nitrogen, (D) organic matter $(\mathrm{OM})$ and $\delta^{13} \mathrm{C}$ for organic carbon, (E) myxoxanthophyll (colonial cyanobacteria) and allozanthin (cryptophytes), (F) lutein-zeaxanthin (chlorophytes, cyanobacteria) and diatoxanthin (diatoms), and $(\mathrm{G})$ isorenieratene (green sulfur phototrophic bacteria) and $\beta$ carotene (all algae); (H) a dimensionless water-clarity index (WCI) based on the ratio of pigments from shade-intolerant deepwater bacteria and surface-water algae (isorenieratene: $\beta$-carotene) (Brown et al. 1984); and (I) Peridinium (Per.) cells (as cysts and empty cell membranes) and remains from the cladoceran herbivore Bosmina longirostris (Bos.). All fossil indicators demonstrate that lake production increased coincidently with high-amplitude water-level fluctuations (I, 1918-1919 flood; II, $1928-1929$ flood; III, 1932 impoundment), with production increases markedly higher during the second period of increased water-level fluctuations (V, full operation of NWC; VII, 1991-1992 flood) following draining of the upstream wetlands in 1951-1957 (IV). (VI) The combined period of sewage diversion (beginning 1983) and changes in fishery harvests (beginning 1985) is also indicated. The width of the gray bars on panels (B)-(I) denotes uncertainty in core-slice dating from Fig. 3. Note that modern values for most parameters were reached prior to or slightly after the onset of routine monitoring programs in 1969. 

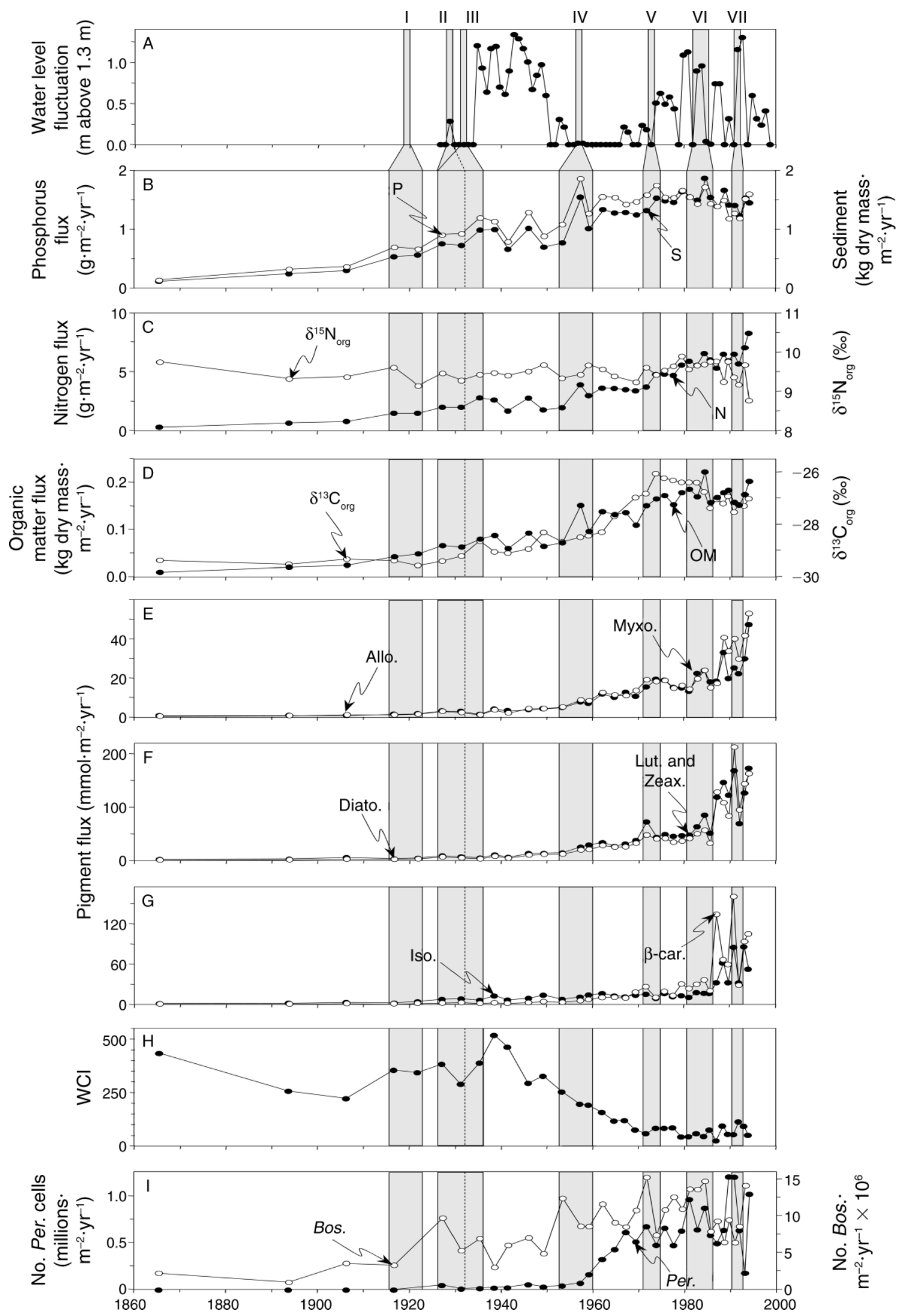
diversion project (1983) and fisheries harvest changes (1985) (Table 1) and declined slightly thereafter to a mean of $\sim 1.44 \mathrm{~kg} \mathrm{DM} \cdot \mathrm{m}^{-2} \cdot \mathrm{yr}^{-1}$, roughly a 13 -fold increase over baseline conditions a century earlier.

Accumulation rates of $\mathrm{P}, \mathrm{N}$, and organic matter (OM) also increased dramatically since the early 1900s, with major peaks of accumulation following the early 20th century floods and impoundment (1919-1932; $1.19 \mathrm{~g}$ $\mathrm{P} \cdot \mathrm{m}^{-2} \cdot \mathrm{yr}^{-1}, 2.75 \mathrm{~g} \mathrm{~N} \cdot \mathrm{m}^{-2} \cdot \mathrm{yr}^{-1}$, and $\left.0.09 \mathrm{~kg} \mathrm{OM} \cdot \mathrm{m}^{-2} \cdot \mathrm{yr}^{-1}\right)$ and the final draining of the Lake Hula wetlands (1957 \pm $3.2 \mathrm{yr} ; 1.86 \mathrm{~g} \mathrm{P} \cdot \mathrm{m}^{-2} \cdot \mathrm{yr}^{-1}, 3.84 \mathrm{~g} \mathrm{~N} \cdot \mathrm{m}^{-2} \cdot \mathrm{yr}^{-1}$, and $0.15 \mathrm{~kg}$ $\left.\mathrm{OM} \cdot \mathrm{m}^{-2} \cdot \mathrm{yr}^{-1}\right)$. Like SAR, accumulation rates of $\mathrm{P}$ and $\mathrm{OM}$ remained high, but relatively constant, during the second phase of high-amplitude water-level fluctuations (1973-1995; $1.48 \mathrm{~g} \mathrm{P} \cdot \mathrm{m}^{-2} \cdot \mathrm{yr}^{-1}$ and $0.17 \mathrm{~kg} \mathrm{OM} \cdot \mathrm{m}^{-2} \cdot \mathrm{yr}^{-1}$ ), a period during which inflows of sewage were curtailed (Table 1). In contrast, $\mathrm{N}$ accumulation rates continued to increase to $8.22 \mathrm{~g} \mathrm{~N} \cdot \mathrm{m}^{-2} \cdot \mathrm{yr}^{-1}$ throughout this period, concomitant with continued and high inputs of nitrates originating from the peat soils of the drained Lake Hula wetland (Avnimelech et al. 1978, Dimentman et al. 1992, Markel et al. 1998).

Unlike the increase in OM accumulation rates, organic carbon remained isotopically depleted (mean $\delta^{13} \mathrm{C}_{\text {org }}=-29.41 \%$ o) throughout the lower fifth of the core, becoming more ${ }^{13} \mathrm{C}$ enriched only toward the end of the period of the early 20th-century floods and impoundment $\left(1935 \pm 4.6 \mathrm{yr}, \delta^{13} \mathrm{C}=-28.7 \%\right.$ ). Organic $\mathrm{C}$ then gradually became more ${ }^{13} \mathrm{C}$ enriched (up to $-26.1 \%$ ) until the beginning of the period of the second phase of high-amplitude water-level fluctuations (1974 $\pm 2.4 \mathrm{yr}$ ), before declining to $-27.3 \%$ by $1994 \pm 1.6 \mathrm{yr}$. The sedimentary $\delta^{15} \mathrm{~N}_{\text {org }}$ signal remained relatively stable through most of the sedimentary sequence (mean $\delta^{15} \mathrm{~N}_{\text {org }} \pm 95 \% \mathrm{CI} ; 9.2 \%$ o $\pm 0.1 \%$ ), except for the sharp decline ca. $1994 \pm 1.6$ yr to $8.6 \%$.

Overall, algal and bacterial pigment concentrations were relatively high, particularly in surface sediments. In replicate analyses, the coefficient of variation was $<15 \%$ for most pigments, suggesting that high variation among surface samples was not an artifact of analytical procedures. As observed by Yacobi et al. (1991), concentrations of many pigments declined with burial depth. In particular, fucoxanthin (siliceous algae, some dinoflagellates) and Chl $a$ (all algae) exhibited first-order decay in the upper $8 \mathrm{~cm}$ (data not shown), while peridinin and other complex epoxy-carotenoids from dinoflagellates were also absent from Lake Kinneret deposits. All of these compounds are known to be extremely labile and poorly preserved in many lakes (e.g., Hurley and Armstrong 1991, Leavitt 1993). Of the less-labile pigments, accumulation rates of alloxanthin (cryptophytes), myxoxanthophyll (colonial cyanobacteria), diatoxanthin (diatoms; occasionally chrysophytes, dinoflagellates), lutein-zeaxanthin (chlorophytes, cyanobacteria), and $\beta$-carotene (all algae) were relatively constant between ca. 1866 and 1922, increased by 3-4 fold following the early 20 th century floods and impoundment (ca. 1928-1957), and by 7-10 fold following the Hula wetland draining (ca. 1957-1973). Accumulation rates of these pigments were variable, but fairly constant during the first half of the second phase of high-amplitude water-level fluctuations (i.e., from ca. 1973 to 1986). However, coincident with the long-term fishery overharvest (1985-1993; Hambright and Shapiro 1997), accumulation rates of these pigments dramatically increased during the last decade of record, with rates exceeding late nineteenth century rates by 40-70 fold. Accumulation rates of isorenieratene from green sulfur phototrophic bacteria were also very low ( 2 $\left.\mathrm{mmol} \cdot \mathrm{m}^{-2} \cdot \mathrm{yr}^{-1}\right)$ at the end of the 19 th century, increased gradually through the early 1980 s, reaching 15 $\mathrm{mmol} \cdot \mathrm{m}^{-2} \cdot \mathrm{yr}^{-1}$ by $1986 \pm 1.9 \mathrm{yr}$. During the last decade (ca. 1986-1995) accumulation of isorenieratene varied between 32 and $85 \mathrm{mmol} \cdot \mathrm{m}^{-2} \cdot \mathrm{yr}^{-1}$.

The WCI declined by $\sim 50 \%$ (from 432 to 221 ) in the latter decade of the 19th century, increased during the period of the early 20th-century floods and impoundment, reaching a maximum of 516 in 1939. The WCI then consistently declined to $<10 \%$ of maximal values by $1972( \pm 2.5 \mathrm{yr})$, and remained low throughout the second period of water-level fluctuations associated with the National Water Carrier (NWC). Similar patterns were also observed for ratios of isorenieratene and lutein-zeaxanthin (cyanobacteria, chlorophytes), diatoxanthin (diatoms), or alloxanthin (cryptophytes), suggesting that inferences of water transparency did not vary with the specific algal carotenoid used in the analysis.

Peridinium remains were absent from the deepest layers of the core. Instead, the first evidence of Peridinium was found in sediments deposited during the early 20th century floods and impoundment (ca. $1927 \pm 5.3 \mathrm{yr}$ ). After 1927, accumulation rates of Peridinium were low (9000-57000 Peridinium $\cdot \mathrm{m}^{-2} \cdot \mathrm{yr}^{-1}$ ) until $1957 \pm 3.2 \mathrm{yr}$, but then increased to $>600000$ Peridinium $\cdot \mathrm{m}^{-2} \cdot \mathrm{yr}^{-1}$ by $1969 \pm 2.6 \mathrm{yr}$. During the second period of high-amplitude water-level fluctuations (1973-1995), Peridinium accumulation rates averaged $>700000$ Peridinium $\cdot \mathrm{m}^{-2} \cdot \mathrm{yr}^{-1}$, although accumulation rates were highly variable after 1990 .

Most zooplankton remains found in the core were of the small cladoceran Bosmina. Fragments of copepods were also common, but because we could not identify a majority of the fragments to genus, we did not quantify their abundances. Daphnia lumholtzi is reported to have been collected from Lake Kinneret in the 1950s (Bromley 1993); however, no Daphnia remains were recovered from any depth interval within the core. Instead, Bosmina remains (Bosmina longirostris typica and B. l. cornuta) were found throughout the core and exhibited similar patterns in accumulation rates as pigments and Peridinium. Accumulation rates of total Bosmina were initially slightly less than 1 million Bosmina $\cdot \mathrm{m}^{-2} \cdot \mathrm{yr}^{-1}$ until increasing to a peak of $\sim 10$ million Bosmina $\cdot \mathrm{m}^{-2} \cdot \mathrm{yr}^{-1}$ during the period of the early 20th-century floods and 
impoundment. Subsequently Bosmina accumulation rates increased gradually to 15 million Bosmina $\cdot \mathrm{m}^{-2} \cdot \mathrm{yr}^{-1}$ by the beginning of the second period of high-amplitude waterlevel fluctuations. During 1973-1995 Bosmina accumulation rates remained generally high (averaging $\sim 10$ million Bosmina $\cdot \mathrm{m}^{-2} \cdot \mathrm{yr}^{-1}$ ), although rates fluctuated between 6.3 and 14.6 million Bosmina $\cdot \mathrm{m}^{-2} \cdot \mathrm{yr}^{-1}$.

Depth-constrained cluster analysis generally confirmed that the timing of ecosystem change corresponded closely with known hydrological and anthropogenic events (Fig. 5). Specifically, substantial synchronous changes in fossil assemblages appeared to occur ca. 1916-1933 (floods, impoundment), 1946-1957 (Lake Hula draining), 1967-1974 (full operation of NWC), and 1984-1989 (sewage diversion, shift in fisheries practices). Additionally, cluster analysis revealed multiple changes in fossil assemblages within the upper $6 \mathrm{~cm}$ of the core (i.e., 1986-1995) consistent with the high frequency variation in primary production and biogeochemical cycles documented by the Kinneret Limnological Laboratory monitoring program (see, for example, Zohary et al. 1998, Hambright et al. 2004, Zohary 2004).

\section{Discussion}

A striking feature of the sedimentary record was that all parameters examined (except stable nitrogen isotopes) revealed distinct changes in trajectories corresponding approximately to the period 1916-1933, a period concomitant with the early 20th-century floods and impoundment of the lake in 1932. Although there are no water-level data available prior to 1926, it seems logical that large water-level fluctuations would have occurred with the flood in 1918-1919, similar to that observed with the flood in 1928-1929 (0.3 m above the normal 1.3-m fluctuation). Operation of the hydroelectric station marked the beginning of artificial, highamplitude water-level fluctuations, with seasonal fluxes in water levels averaging over $2 \mathrm{~m}$. Because of greater uncertainties associated with ${ }^{210} \mathrm{~Pb}$ analysis of deep core samples, we cannot statistically distinguish between the early 20th-century floods and the 1932 completion of impoundment. Despite this caveat, we note that accumulation rates of most parameters examined increased dramatically from baseline conditions at the turn of the century when water-level fluctuations increased significantly (cf. Figs. 2, 4, and 5). Accumulation rates of these parameters continued to increase, with peaks in accumulation rates associated with the completion of the Hula wetlands draining project (1957), and operation of Lake Kinneret as Israel's freshwater storage and supply reservoir (1964-1995, with maximum-capacity pumping since 1973). These patterns suggest that engineered hydrological changes, coupled with occasional heavy winter flooding have had a strong impact on the physical, chemical, and biological dynamics of the lake. Moreover, patterns in most parameters suggest that the draining of the Lake Hula wetlands (1957) and the second phase of increased lake

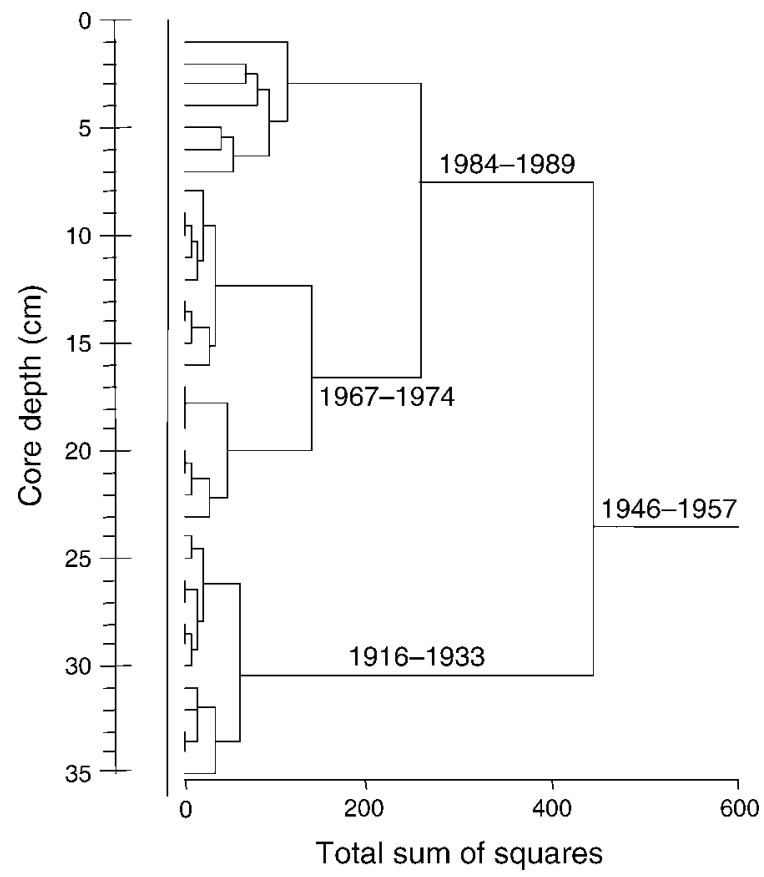

FIG. 5. Results of depth-constrained cluster analysis on all fossil data combined showing separation in data coincident with key hydrological modifications and lake-management activities. The split between core depths 31 and $30 \mathrm{~cm}$ represents (within 95\% CI) the period 1916-1933 and is coincident with lake impoundment; between 24-23 cm represents 1946-1957 and is coincident with the Hula wetlands draining; between 17 $16 \mathrm{~cm}$ represents 1967-1974 and is coincident with operation of NWC; and between 8-7 cm represents 1984-1989 and is coincident with sewage diversion and fishery management changes.

water-level fluctuations (1973-1995), coupled with further changes in watershed hydrology and fishery harvest practices, led to more dramatic changes in ecosystem production than did initial lake impoundment.

Bulk sediment, $\mathrm{P}, \mathrm{N}$, and organic-matter accumulation rates in the central area of Lake Kinneret during the period 1973-1995 represent increases of 600-1200\% over the accumulation rates recorded for the late 19th century. Based on a mass-balance analysis of P fluxes, Hambright et al. (2004) concluded that management strategies designed to increase the supply of water had also inadvertently increased $\mathrm{P}$ retention by the lake, favoring the development of eutrophic conditions. Briefly, their analysis noted that nutrient export was greatest in spring when water column concentrations are typically greatest due to high influx associated with winter rain, and holomixis that redistributed nutrient-rich bottom waters to the surface. However, following impoundment, water outflows from the lake became less seasonal, as demand for water for hydroelectric production (1932-1948) or for domestic and agricultural supply (1964-1995) were more evenly spread across the year. As a result of shifting a higher proportion of water outflow to the summer and fall, the period when the lake was thermally and 
chemically stratified and concentrations of most nutrients lower in the epilimnion, outflows were relatively nutrient poor and higher amounts of nutrients remained in the lake basin. Consistent with this view, our new analysis reveals that the increase in nutrient retention and changes in nutrient accumulation rates coincided with greatly increased algal and invertebrate productivity, as revealed by patterns in accumulation rates of organic matter, phytoplankton and bacterial pigments, and remains of phytoplankton and zooplankton.

Comparison of stratigraphies from pigments of differing chemical lability suggests that many fossil pigments recorded changes in plankton communities or lake structure, and not simply artifacts of postdepositional degradation of labile compounds (e.g., Chl a) (Yacobi et al. 1991). For instance, changes in fossil carotenoids record temporal variation in algal abundances (Leavitt and Findlay 1994; reviewed in Leavitt and Hodgson [2001]), and these stable compounds did not exhibit exponential decay profiles. Instead, alloxanthin (cryptophytes), myxoxanthophyll (colonial cyanobacteria), diatoxanthin (diatoms; occasionally chrysophytes, dinoflagellates), and lutein-zeaxanthin (chlorophytes, cyanobacteria) were relatively constant in the deepest $5 \mathrm{~cm}$ of the core (1866-1922), increasing by $3-4$ fold by 1957 , and $7-10$ fold by 1973 . Concentrations of these pigments were variable, but fairly constant from 1973 to 1986, and then dramatically increased during the last decade of record, with concentrations exceeding late 19th century concentrations by $40-70$ times. While it is impossible to completely rule out the possibility that some changes in fossil concentrations arose from post-depositional degradation of pigments (Yacobi et al. 1991, Leavitt and Findlay 1994), these patterns are consistent with historical increases in the abundances of green algae and cyanobacteria recorded in the scientific monitoring program of Lake Kinneret (see Fig. 1), and with a sharp increase in the $\delta^{13} \mathrm{C}$ signal seen in this (Fig. 4D) and earlier cores (Stiller and Kaufman 1985, Dubowski et al. 2003). In particular, changes in the $\delta^{13} \mathrm{C}$ signal of organic sediments were highly correlated with the increased productivity by the biomass-dominant taxon Peridinium remains $\left(r^{2}=0.623 ; \mathrm{df}=32 ; F=51.3 ; P<\right.$ 0.001 ) and with pigment accumulation rates (all pigments in Fig. 4 combined; $r^{2}=0.304 ; \mathrm{df}=32 ; F=$ $14.0 ; P=0.001)$, consistent with historical changes in algal production, rather than fossil artifacts.

Historical changes in isorenieratene from green sulfur phototrophic bacteria relative to carotenoids derived from planktonic algae are also consistent with eutrophication and commensurate changes in the photic environment of Lake Kinneret. Chlorobiaceae are obligate anaerobes that use $\mathrm{H}_{2} \mathrm{~S}$ as an electron donor for photosynthesis (Pfennig 1978). The presence of this taxonomically diagnostic carotenoid indicates both that the hypolimnion or sediments of Lake Kinneret were largely anoxic and that light penetrated to the anoxic habitats (Brown et al. 1984). Therefore, elevated concentrations of isorenieratene since the 1920s and 1930s and particularly in the last decade represented by our core (1985-1995) are consistent with improved habitat for the obligate anaerobes, due either to improved light penetration or development of more profound anoxia and concentrated $\mathrm{H}_{2} \mathrm{~S}$ sources (Brown et al. 1984, Leavitt et al. 1989). Comparison of the pattern for isorenieratene to that for $\beta$-carotene (i.e., the water-clarity index, WCI) supports the latter hypothesis. Both pigments are simple unsubstituted carotenes (Davies 1976) that exhibit similar post-depositional degradation dynamics (Hurley and Armstrong 1991, Leavitt 1993) and should not be subject to biases arising from differential post-depositional degradation. Consequently, interpretation of changes in ratios of isorenieratene to $\beta$-carotene indicate that water clarity of Lake Kinneret declined since the 1930s and reached low, but stable, values since the 1970s. Although such a decline in the ratio could indicate an increase in epilimnion thickness, thereby reducing the amount of light penetration to the upper hypolimnion, this alternative hypothesis is unlikely because epilimnion thickness in Lake Kinneret decreased by nearly $3 \mathrm{~m}$ between 1969 and 1992, as predicted by general heat models (Mazumder et al. 1990, Hambright 1994, Hambright et al. 1994). Instead we believe that declines in water clarity since ca. 1930 are consistent with long-term eutrophication of Lake Kinneret due to persistent hydrologic modification and increased nutrient retention.

Our paleolimnological analyses also revealed that plankton composition was substantially altered during the period of intense hydrologic management. For example, although its signatory pigments (peridinin, dinoxanthin) are extremely labile and were not detected in the sediments, Peridinium remains were present in sediments deposited since the early 20th-century floods and impoundment (i.e., $1927 \pm 5.3 \mathrm{yr}$ ). However, in contrast to its predominance in modern phytoplankton samples (cf. Fig. 1), fossil analyses revealed that this prominent and characteristic Lake Kinneret species was likely a minor component of the plankton prior to the 1930s, that its abundance increased slightly following impoundment and dramatically following wetland draining. This chronology of change contradicts qualitative statements that Peridinium blooms have always been a characteristic of the Lake Kinneret plankton (e.g., Berman et al. 1998), but is consistent with published reports of Peridinium occurrence and development. For example, Peridinium was not described from Lake Kinneret until the mid-20th century (Komarovsky 1951, Rayss 1951), despite the presence of other dinoflagellates (e.g., Ceratium hirudinella) since at least 1890 (Barrois 1894). Similarly, Yashouv and Alhunis (1961) described the spring phytoplankton in 1957 as composed mainly of Ceratium and Peridinium, while Pollingher and Kimor (1970) recorded spring Peridinium blooms in 1965, 1966, and 1967, but noted that 
Peridinium was conspicuously absent in 1964. From 1969 to 1995 the spring Peridinium bloom was recorded every year (Zohary 2004), but beginning with 1996, Peridinium blooms have become less predictable: no blooms occurred in 1996, 1997, 2000, 2001, 2005, and 2006 (Zohary 2004; T. Zohary, unpublished data). Thus, it appears that the spring blooms of Peridinium were a transient feature in the long-term ecological development of Lake Kinneret.

The sedimentary record of Bosmina production corroborates historical changes in algal abundances, and presumably herbivore resources, during the 20th century. Accumulation rates of Bosmina increased throughout the core, with peaks coincident with the early 20th-century floods and impoundment. Although such increases reflect either higher food availability and grazer production, or reduced zooplanktivory, we favor the former hypothesis because of concomitant increases in inferred algal production, and because there were no significant changes in either remains of large-bodied grazers (e.g., Daphnia) or the morphology of Bosmina remains (data not shown), both sensitive indices of predation by fish and macroinvertebrates (Kitchell and Kitchell 1980, Kerfoot 1981, Leavitt et al. 1989). Moreover, analysis of long-term commercial fish harvests of the lake indicates a trend of increased fishery production since the 1940s that would have yielded higher (not lower) predation pressure on the zooplankton assemblage (Hambright and Shapiro 1997, Walline et al. 2000). Indeed, recent analyses of zooplankton during the 1980s and 1990s indicate that zooplankton biomass and mean body sizes declined during this period (Roelke et al. 2007; K. D. Hambright, unpublished manuscript).

Formal scientific study of Lake Kinneret began in 1969 with establishment of the Yigal Allon Kinneret Limnological Laboratory (Serruya 1978). Since that time, Lake Kinneret has become one of the most thoroughly studied freshwater lakes, with over 1000 publications in such fields as geology, chemistry, ecology, hydrology, economics, and history (Arad et al. 1998, Hambright and Hershcovitch 1998). Based on much of this wealth of knowledge, particularly that associated with Peridinium and high primary productivity, it has often been suggested that Lake Kinneret represents one of the best known examples of year-toyear stability in a freshwater ecosystem (Berman et al. 1992, Reynolds 2002). Our paleolimnological analysis shows clearly that the high level of production of Lake Kinneret, characterized by seasonal blooms of Peridinium, is a recently acquired attribute and that the ecosystem configuration noted during 1969-1995 represents a drastically different ecosystem compared to that which existed in the late 19th and early 20th centuries. Moreover, the notable stability of the 1969-1995 period seems now to have been lost, as Peridinium blooms have become unpredictable, outbreaks of $\mathrm{N}$-fixing and other cyanobacteria are common, and various green algae and diatoms have become more prevalent (Zohary 2004, Roelke et al. 2007).

Access to and exploitation of freshwater resources have been historically important to political, economic, and social issues worldwide (McCaffrey 1993, Postel et al. 1996, Gleick 2004). Since the construction of Israel's National Water Carrier (NWC) in 1964, Lake Kinneret has served a central role in the regional economy, with 200-400 million cubic meters of water pumped annually from the lake, in an effort to meet the fresh-water demands of Israel, and also of Jordan and the Palestinian territories (Ben-Meir 2000, Kislev 2005). With domestic development and increased realization that regional water resources must be shared, there is pressure on the Israeli government to further increase the lake's supply capacity with further reductions in summer water levels (Hambright et al. 2000, Hambright and Zohary 2005). At the end of summer 2001, due to successive low-rainfall years and increased population, hence increased demand for water, Lake Kinneret reached its lowest recorded level, $5.8 \mathrm{~m}$ below full capacity (Hambright and Zohary 2005), and watercolumn measures of water quality for 2003 were the lowest on record since water-quality quantification began in 1994 (Parparov and Hambright 2007). Unfortunately, our results indicate that the engineered hydrological changes to Lake Kinneret and its watershed, possibly coupled with inappropriate fisheries management (Hambright and Shapiro 1997) during the previous century have markedly increased lake eutrophication, and warn that further hydrological modification (e.g., further reductions in water levels) could severely impair water supply and further deteriorate water quality and ecosystem stability for future generations (Vitousek et al. 1997). Because such waterresource management strategies are common in other dry regions of the world, Lake Kinneret may serve both as a model system for such lakes and as a warning of the consequences of management strategies that emphasize water quantity over quality.

\section{ACKNOWLEDGMENTS}

We thank C. Teichreb, M. Graham, R. Vinebrooke, Y. Winer, E. Uri, T. Fishbein, J. Easton, and M. Hatab for technical assistance. S. McGowan provided valuable comments on an earlier version of this paper. Funding was provided by the Israel Ministry of Energy and Infrastructures, by the Natural Sciences and Engineering Research Council of Canada (NSERC) through a Kalium Professorship in Engineering and Science (University of Regina) to P. R. Leavitt, and by the University of Oklahoma College of Arts and Sciences and the Biological Station.

\section{Literature Cited}

Appleby, P. G., and F. Oldfield. 1983. The assessment of ${ }^{210} \mathrm{~Pb}$ data from sites with varying sediment accumulation rates. Hydrobiologia 103:29-35.

Arad, V., Y. Bartov, and K. D. Hambright. 1998. Lake Kinneret research: bibliography. Israel Oceanographic and Limnological Research and the Ministry of National Infrastructures, Haifa, Israel. 
Avnimelech, Y., S. Dasberg, A. Harpaz, and I. Levin. 1978. Prevention of nitrate leakage from Hula basin, Israel: a case study in water management. Soil Science 125:233-239.

Azoulay, B. 2002. The autecology of the new invader Eudiaptomus dreischi in Lake Kinneret. Dissertation. Hebrew University of Jerusalem, Jerusalem, Israel.

Barrois, T. 1894. Contribution à l'ètude de quelques lacs de Syrie. Revue Biologique du Nord de la France 6:224-312.

Ben-Meir, M. 2000. Water storage capacity in Israel. Archiv für Hydrobiologie Beiheft Ergebnisse der Limnologie 55:1-5.

Ben-Tuvia, A., E. B. Davidoff, J. Shapiro, and D. Shefler. 1992. Biology and management of Lake Kinneret fisheries. The Israeli Journal of Aquaculture (formerly Bamidgeh) 44:4865.

Berman, T., U. Pollingher, and T. Zohary. 1998. A short history of stability and change in phytoplankton populations in Lake Kinneret. Israel Journal of Plant Science 46:73-80.

Berman, T., L. Stone, Y. Z. Yacobi, B. Kaplan, M. Schlichter, A. Nishri, and U. Pollingher. 1995. Primary production and phytoplankton in Lake Kinneret: a long-term record (19721993). Limnology and Oceanography 40:1064-1076.

Berman, T., Y. Z. Yacobi, and U. Pollingher. 1992. Lake Kinneret phytoplankton: stability and variability during twenty years (1970-1989). Aquatic Sciences 54:104-127.

Bollhöfer, A., A. Mangini, A. Lenhard, M. Wessels, F. Giovanoli, and B. Schwarz. 1994. High-resolution ${ }^{210} \mathrm{~Pb}$ dating of Lake Constance sediments: stable lead in Lake Constance. Environmental Geology 24:267-274.

Bromley, H. J. 1993. A checklist of the Cladocera of Israel and Eastern Sinai. Hydrobiologia 257:21-28.

Brown, J. H., J. F. Gillooly, A. P. Allen, V. M. Savage, and G. B. West. 2004. Toward a metabolic theory of ecology. Ecology 85:1771-1789.

Brown, S. R., H. J. McIntosh, and J. P. Smol. 1984. Recent paleolimnology of a meromictic lake: fossil pigments of photosynthetic bacteria. Internationale Vereinigung für Theoretische und Angewandte Limnologie, Verhandlungen 22:1357-1360.

Carpenter, S. R. 2005. Eutrophication of aquatic ecosystems: Bistability and soil phosphorus. Proceedings of the National Academy of Sciences (USA) 102:10002-10005.

Coe, M. T., and J. A. Foley. 2001. Human and natural impacts on the water resources of the Lake Chad basin. Journal of Geophysical Research D: Atmospheres 106:3349-3356.

Cottingham, K. L., J. A. Rusak, and P. R. Leavitt. 2000. Increased ecosystem variability and reduced predictability following fertilization: evidence from paleolimnology. Ecology Letters 3:340-348.

Davies, B. H. 1976. Carotenoids. Pages $38-165$ in T. W Goodwin, editor. Chemistry and biochemistry of plant pigments. Academic Press, New York, New York, USA.

Dimentman, C., H. J. Bromley, and F. D. Por. 1992. Lake Hula: reconstruction of the fauna and hydrobiology of a lost lake. Israel Academy of Sciences and Humanities, Jerusalem, Israel.

Dubowski, Y., J. Erez, and M. Stiller. 2003. Isotopic paleolimnology of Lake Kinneret. Limnology and Oceanography 48:68-78.

Gleick, P. H. 2004. The world's water, 2001-2002: the biennial report on freshwater resources. Island Press, Washington, D.C., USA.

Goldberg, E. D. 1963. Geochronology with lead-210. Pages 121-131 in Proceedings of a Symposium on Radioactive Dating. International Atomic Energy Agency (United Nations), Vienna, Austria.

Gophen, M. 1992. Long-term changes of plankton communities in Lake Kinneret, Israel. Asian Fisheries Science 5:291-302.

Gophen, M., R. W. Drenner, and G. L. Vinyard. 1983a. Cichlid stocking and the decline of the Galilee Saint Peter's fish (Sarotherodon galilaeus) in Lake Kinneret, Israel. Canadian Journal of Fisheries and Aquatic Sciences 40:983-986.
Gophen, M., R. W. Drenner, and G. L. Vinyard. 1983b. Fish introductions into Lake Kinneret: call for concern. Fisheries Management 14:43-45.

Grimm, E. C. 1987. CONISS: A FORTRAN 77 program for stratigraphically constrained cluster analysis by the incremental sum of squares. Computers and Geosciences 13:13-35.

Hambright, K. D. 1994. Can zooplanktivorous fish really affect lake thermal dynamics? Archiv für Hydrobiologie 4:429-438.

Hambright, K. D., W. Eckert, P. R. Leavitt, and C. L. Schelske. 2004. Effects of historical lake level and land use on sediment and phosphorus accumulation rates in Lake Kinneret. Environmental Science and Technology 38:6460-6467.

Hambright, K. D., M. Gophen, and S. Serruya. 1994. Influence of long-term climatic changes on the stratification of a subtropical, warm monomictic lake. Limnology and Oceanography 39:1233-1242.

Hambright, K. D., and R. Hershcovitch. 1998. Kinneret Limnological Laboratory Bibliography, 1968-1998. Israel Oceanographic and Limnological Research, Haifa, Israel.

Hambright, K. D., A. R. Parparov, and T. Berman. 2000. Indices of water quality for sustainable management and conservation of an arid region lake, Lake Kinneret (Sea of Galilee), Israel. Aquatic Conservation: Marine and Freshwater Ecosystems 10:393-406.

Hambright, K. D., and J. Shapiro. 1997. The 1993 collapse of the Lake Kinneret commercial bleak fishery. Fisheries Management and Ecology 4:275-283.

Hambright, K. D., and T. Zohary. 1999. The Hula Valley (Northern Israel) wetlands rehabilitation project. Pages 173180 in W. Streever, editor. International perspectives in wetlands rehabilitation. Kluwer Academic Press, Dordrecht, The Netherlands.

Hambright, K. D., and T. Zohary. 2005. Lake Kinneret and water supply in Israel: ecological limits to operational supply. Pages 111-124 in K. D. Hambright, J. Ragep, and J. Ginat, editors. Water in the Middle East: cooperation and technological solutions in the Jordan Valley. University of Oklahoma Press, Norman, Oklahoma, USA.

Hambright, K. D., T. Zohary, and W. Eckert. 1997. Potential influence of low water levels on Lake Kinneret: re-appraisal and modification of an early hypothesis. Limnologica 27 : 149-155.

Hambright, K. D., T. Zohary, and H. Güde. 2007. Microzooplankton dominate carbon flow and nutrient cycling in a warm subtropical freshwater lake. Limnology and Oceanography 52:1018-1025.

Hurley, J. P., and D. E. Armstrong. 1991. Pigment preservation in lake sediments: a comparison of sedimentary environments in Trout Lake, Wisconsin. Canadian Journal of Fisheries and Aquatic Sciences 48:472-486.

Kerfoot, W. C. 1981. Long-term replacement cycles in cladoceran communities: a history of predation. Ecology 62:216-233.

Kislev, Y. 2005. The water economy of Israel. Pages 127-150 in K. D. Hambright, J. Ragep, and J. Ginat, editors. Water in the Middle East: cooperation and technological solutions in the Jordan Valley. University of Oklahoma Press, Norman, Oklahoma, USA.

Kitchell, J. A., and J. F. Kitchell. 1980. Size-selective predation, light transmission, and oxygen stratification: evidence from the recent sediments of manipulated lakes. Limnology and Oceanography 25:389-402.

Komarovsky, B. 1951. Some characteristic water-blooms in Lake Tiberias and fish ponds in the Jordan Valley. Internationale Vereinigung für Theoretische und Angewandte Limnologie 11:219-223.

Leavitt, P. R. 1993. A review of factors that regulate carotenoid and chlorophyll deposition and fossil pigment abundance. Journal of Paleolimnology 9:109-127.

Leavitt, P. R., S. R. Carpenter, and J. F. Kitchell. 1989. Wholelake experiments: the annual record of fossil pigments and zooplankton. Limnology and Oceanography 34:700-717. 
Leavitt, P. R., and D. L. Findlay. 1994. Comparison of fossil pigments with 20 years of phytoplankton data from eutrophic Lake 227, Experimental Lakes Area, Ontario. Canadian Journal of Fisheries and Aquatic Sciences 51:22862299.

Leavitt, P. R., and D. A. Hodgson. 2001. Sedimentary pigments. Pages $295-325$ in J. P. Smol, H. J. B. Birks, and W. M. Last, editors. Tracking environmental change using lake sediments. Volume 3. Terrestrial, algal and siliceous indicators. Kluwer, Dordrecht, The Netherlands.

Mantoura, R. F. C., and C. A. Llewellyn. 1983. The rapid determination of algal chlorophyll and carotenoid pigments and their breakdown products in natural waters by reversephase high-performance liquid chromatography. Analytica Chimica Acta 151:297-314.

Markel, D., E. Sass, B. Lazar, and A. Bein. 1998. Biogeochemical evolution of a sulfur-iron rich aquatic system in a reflooded wetland environment (Lake Agmon, northern Israel). Wetlands Ecology and Management 6:103-120.

Mazumder, A., W. D. Taylor, D. J. McQueen, and D. R. S. Lean. 1990. Effects of fish and plankton on lake temperature and mixing depth. Science 247:312-315.

McCaffrey, S. C. 1993. Water, politics, and international law. Pages 92-104 in P. H. Gleick, editor. Water in Crisis. Oxford University Press, New York, New York, USA.

Micklin, P. P. 1988. Dessication of the Aral Sea: a water management disaster in the Soviet Union. Science 241:11701176.

Nun, M. 1974. Water levels in Lake Kinneret in the historical period. Land and Nature 15:212-218.

Oganesian, R. O., and A. S. Parparov. 1989. The problems of Lake Sevan and ways of solution. Pages 367-378 in J. Salanki and S. Herodek, editors. Symposium Biologica Hungarica, Conservation and Management of Lakes. Akademiai Kiado, Budapest, Hungary.

Ostrovsky, I., and P. Walline. 2001. Multi-annual changes in the pelagic fish Acanthobrama terraesanctae in Lake Kinneret (Israel) in relation to food sources. Internationale Vereinigung für Theoretische und Angewandte Limnologie, Verhandlungen 27:2090-2094.

Parparov, A. R., and K. D. Hambright. 2007. Composite water quality: evaluation and management feedbacks. Water Quality Research Journal of Canada 42:20-25.

Pennington, W., R. S. Cambray, and E. M. Fisher. 1973. Observations on lake sediments using fallout ${ }^{137} \mathrm{Cs}$ as a tracer. Nature 242:324-326.

Pfennig, N. 1978. General physiology and ecology of photosynthetic bacteria. Pages 1-18 in R. K. Clayton and W. R. Sistrom, editors. The photosynthetic bacteria. Plenum Press, New York, New York, USA.

Pollingher, U. 1981. The structure and dynamics of the phytoplankton assemblages in Lake Kinneret, Israel. Journal of Plankton Research 3:93-105.

Pollingher, U., O. Hadas, Y. Z. Yacobi, T. Zohary, and T. Berman. 1998. Aphanizomenon ovalisporum (Forti) in Lake Kinneret, Israel. Journal of Plankton Research 20:13211339.

Pollingher, U., and B. Kimor. 1970. Seasonal and bathymetric changes in the composition of the phytoplankton population of Lake Tiberias based on biomass estimations during the years 1964-1967. Ministry of Agriculture, Department of Fisheries, Haifa, Israel.

Postel, S. L., G. C. Daily, and P. R. Ehrlich. 1996. Human appropriation of renewable fresh water. Science 271:785-788.
Rayss, T. 1951. Materiaux pour la flore algologique de la Palestine: II. Les algues des eaux continentales. Palestine Journal of Botany 5:71-95.

Reynolds, C. S. 2002. On the interannual variability in phytoplankton production in freshwaters. Pages 187-221 in P. J. L. B. Williams, D. N. Thomas, and C. S. Reynolds, editors. Phytoplankton productivity: carbon assimilation in marine and freshwater ecosystems. Blackwell Science, Oxford, UK.

Roelke, D. L., T. Zohary, and K. D. Hambright. 2007. Alternative states in the phytoplankton of Lake Kinneret, Israel (Sea of Galilee). Freshwater Biology 52:399-411.

Savage, C., P. R. Leavitt, and R. Elmgren. 2004. Distribution and retention of effluent nitrogen in surface sediments of a coastal bay. Limnology and Oceanography 49:1503-1511.

Schelske, C. L., A. Peplow, M. Brenner, and C. N. Spencer. 1994. Low-background gamma counting: applications for ${ }^{210} \mathrm{~Pb}$ dating of sediments. Journal of Paleolimnology 10:115128.

Schindler, D. W. 1987. Detecting ecosystem responses to anthropogenic stress. Canadian Journal of Fisheries and Aquatic Sciences 44(Supplement 1):6-25.

Serruya, C., editor. 1978. Lake Kinneret. Dr. Junk Publishers, The Hague, The Netherlands.

Stiller, M. 1979. The influence of Lake Hula drainage on the ${ }^{14} \mathrm{C}$ record and on the sedimentation rate in Lake Kinneret. Israel Journal of Earth Sciences 28:1-12.

Stiller, M., and A. Kaufman. 1985. Paleoclimatic trends revealed by the isotopic composition of carbonates in Lake Kinneret. Zeitschrift für Gletscherkunde und Glazialgeologie 21:79-87.

Vitousek, P. M., H. A. Mooney, J. Lubchenco, and J. M. Melillo. 1997. Human domination of Earth's ecosystems. Science 277:494-499.

Walline, P. D., J. A. Tyler, S. B. Brandt, I. Ostrovsky, and J. M. Jech. 2000. Lavnun abundance: how changes may affect consumption of Lake Kineret zooplankton. Archiv für Hydrobiologie Beiheft Ergebnisse der Limnologie 55:493511.

Wolf, A. T. 1995. Hydropolitics along the Jordan River: the impact of scarce water resources on the Arab-Israeli conflict. United Nations University Press, Tokyo, Japan.

Yacobi, Y. Z., R. F. C. Mantoura, and C. A. Llewellyn. 1991. The distribution of chlorophylls, carotenoids and their breakdown products in Lake Kinneret (Israel) sediments. Freshwater Biology 26:1-10.

Yashouv, A., and M. Alhunis. 1961. The dynamics of biological processes in Lake Tiberias. The Bulletin of the Research Council of Israel 10B:12-35.

Yoffe, S., A. T. Wolf, and M. Giordano. 2003. Conflict and cooperation over international freshwater resources: indicators of basins at risk. Journal of the American Water Resources Association 39:1109-1126.

Zohary, T. 2004. Changes to the phytoplankton assemblage of Lake Kinneret after decades of a predictable repetitive pattern. Freshwater Biology 49:1355-1371.

Zohary, T., and A. Gasith. 2006. Sardine dilution in Lake Kinneret: re-assessment. Agamit 178:29-31.

Zohary, T., U. Pollingher, O. Hadas, and K. D. Hambright. 1998. Bloom dynamics and sedimentation of Peridinium gatunense in Lake Kinneret. Limnology and Oceanography 43:175-186. 